\title{
Makna Simbolik Haji dalam Perspektif Masyarakat Bugis
}

\author{
Nasruddin $^{1^{*}}$ \\ ${ }^{1}$ IImu Pendidikan Sosial, IAIN Parepare,Indonesia \\ *Korespondensi: nasruddinsoni@iainpare.ac.id
}

\begin{tabular}{c}
\hline Info Artikel \\
\hline Diterima 29 \\
Oktober 2021 \\
Disetujui 12 \\
November 2021 \\
Dipublikasikan 15 \\
November 2021 \\
Keywords: \\
Haji, Makna, \\
Masyarakat Bugis, \\
Simbolik \\
(C) 2021 The \\
Author(s): This is \\
an open-access \\
article distributed \\
under the terms of \\
the Creative \\
Commons \\
Attribution \\
ShareAlike (CC BY- \\
SA 4.0) \\
(C) (7) (9) \\
By sA
\end{tabular}

\begin{abstract}
Abstrak
Simbol haji menunjukkan corak dengan berbagai interpretasi makna yang akan melekat pada masyarakat Bugis. Penelitian ini bertujuan untuk mengungkapkan makna simbolik haji dalam perspektif masyarakat Bugis. Penelitian ini dilakukan di Kecamatan Soppeng Riaja Kabupaten Barru. Jenis penelitian ini adalah kualitatif dengan menggunakan pendekatan interaksi simbolik. Hasil penelitian ini mengungkapkan empat makna dalam simbolik haji. Pertama adalah konsep takdir di mana takdir menjadi penentu bagi masyarakat Bugis untuk pergi Haji. Kedua, kesuksesan hidup yang dimaknai bahwa rezeki seseorang dimudahkan jika ia sudah berhaji. Ketiga adalah istita'ah yang merupakan kemapanan rohani dan jasmani. Keempat adalah makna ritual mappatoppo yang berkaitan dengan rasa syukur.
\end{abstract}

\section{Abstract}

The symbol of Hajj shows a pattern with various interpretations of meaning that will be attached to the Bugis community. The research aims to reveal the symbolic meaning of Hajj in the perspective of the Bugis people. This research was conducted in Soppeng Riaja District of Barru Regency. This type of research is qualitative using a symbolic interaction approach. The results of this study diclose four meanings in symbolic Haij. First is the concept of destiny where destiny becomes the determinant of Buginese society to go hajj. Second, the success of life means that a person's sustenance is facilitated if he has prayed. The third is istita'ah which is a spiritual and physical establishment. Fourth is the meaning of mappatoppo rituals related to do with the gratitude.

\section{Pendahuluan}

Seiring dengan perkembangan dan tuntutan zaman, sara' (syariat Islam) ikut andil dalam memberikan corak serta mengubah cara pandang masyarakat Bugis dalam menginterpretasikan konsep pangngadereng. Sistem pranata budaya yang dimasukkan ke dalam sistem pranata sosial disebut pangngadereng. Orang Bugis melihat bahwa pangngadereng bukan hanya dipandang sebagai warisan masa lalu, akan tetapi masyarakat Bugis juga memandangnya sebagai bagian masa depan yang harus digunakan secara inovatif. Oleh karena itu, Dengan kehadiran sara' (syariat Islam) di dalam unsur pangngadereng, orang Bugis menginginkan adanya redefinisi dan rekonstruksi konsep pangngadereng ke dalam setiap sendi- 
sendi kehidupan masyarakat Bugis (Mattulada, 1980). Karena sara' (syariat Islam) mampu beradaptasi dan memberikan edukasi serta memberikan arah yang lebih progresif kepada semua unsur-unsur yang ada dalam konsep pangngadereng, sehingga mampu melampaui masa lalunya secara kreatif, radikal, komprehensif, dan dapat mengambil peran dalam berbagai aspek kehidupan. Dengan demikian, pangngadereng di dalam budaya Bugis tidak hanya dipandang sebagai kebudayaan masa lalu, tetapi ia merupakan pengakuan atas suatu pandangan sebagai totalitas dari kehidupan masa sekarang dan yang akan datang. Islamisasi Bugis merupakan sebuah fase penting dalam sejarah kehidupan masyarakatBugis.

Rekonstruksi pemaknaan terhadap konsep pangngadereng dalam tata kehidupan masyarakat Bugis harus dilakukan dengan penekanan bahwa kebenaran yang terkandung di dalam pangngadereng tidak terletak pada simbolnya, akan tetapi terletak pada pandangan dan pikiran serta pemaknaan secara subtansial. Apalagi sejak dimasukkannya sara' ke dalam unsur-unsur pangngadereng justru malah lebih memperkuat, mempertajam serta memberikan kemurnian dalam setiap ucapan, sikap, dan tindakan yang diajarkan oleh sara' (syariat Islam) itu sendiri.

Internalisasi unsur sara' ke dalam unsur-unsur pangngadereng yang lain seperti ade'(adat-istiadat), bicara (peradilan), rapang (perumpamaan) dan wari' (stratifikasi sosial). Memberikan corak dan inspirasi serta aspirasi ke dalam falsafah hidup orang Bugis, sehingga hubungan antara Islam dan orang Bugis masuk ke dalam batin dan menjadi jati diri pada setiap kehidupannya. Sara' (syariat Islam) telah mengubah pola pikir dan kepribadian orang Bugis, sehingga mereka siap untuk mengorbankan nyawa apabila Islam dihina. Begitu pula dalam interaksi sosial. Jika menamakan Islam maka mereka akan membantu tanpa melihat latar belakang sosial dan etnis seseorang (Rustan, 2018).

Sejak masuknya Islam ke tanah Bugis, masyarakat Bugis berlomba-lomba memeluk agama Islam sebagai agama resmi mereka. Penyebaran agama Islam dilakukan dengan pola penyebaran top-down (dari petinggi kerajaan ke masyarakatnya).Penyebar agama Islam mampu membawakan syariat Islam tanpa menimbulkan ancaman dan benturan terhadap institusi sosial budaya serta berbagai kepercayaan lokal yang telah hidup di tengah masyarakat. Pada akhirnya, agama Islam dapat diterima secara ikhlas yang kemudian diintegrasikan ke dalam elemen dasar kebiasaan masyarakat Bugis yang disebut dengan sara' atau syari'at yakni pranata Islam dimasukkan dalam sistem pranata sosial budaya orang Bugis yang disebut dengan konsep pangngadereng (Mattulada, 1980)

Konsep pangngadereng memuat unsur pokok yang mengatur sistem masyarakat Bugis yakni ade' (meliputi semua usaha orang Bugis dalam memperistiwakan diri pada kehidupan bersama di semua lapangan kebudayaan); bicara (mengenai semua aktivitas dan konsep-konsep yang berkaitan dengan peradilan); rapang (perundang-undangan); wari' (mengatur stratifikasi orang Bugis dalam kehidupan bermasyarakat); sara' (hukum syariat yang menggenapkan keempat sendi pangadereng menjadi lima sehingga tersusunlah sendi-sendi kehidupan masyarakat dan kebudayaan orang Bugis) (Mattulada, 1980;1985).

Posisi ibadah haji pada masyarakat Bugis menjadikan ibadah haji ini sebagai ibadah yang senantiasa diorientasikan dan dicita-citakan oleh setiap orang 
Bugis. Dalam perkembangan selanjutnya, ibadah haji ini ternyata tidak sematamata bercorak keagamaan saja, karena corak sosial, ekonomi,dan budaya juga sangat pekat dan kuat di dalamnya. Dengan demikian, ibadah haji ditujukan hanya kepada orang yang mampu untuk menunaikannya. Yang dimaksud disini adalah mereka yang mampu baik secara fisik, finansial maupun secara spiritual, serta lahir batin.

Kategori mampu ini kemudian berkembang ke ranah sosial yang begitu luas dalam masyarakat Bugis. Akibatnya, mampu disini memiliki berbagai macam pandangan di kalangan masyarakat Bugis. Bahkan menurut Syariati (2009), ada yang berpandangan bahwa kemampuan diartikan sebagai orang yang memiliki pendanaan dan kekayaan sehingga mampu membiayai perjalanannya ke Tanah Suci yang semakin lama semakin mahal, tanpa melihat kemampuan psikologis dan kematangan spiritual dalam berhaji. Sehingga tidak heran jika ada beberapa orang Bugis dalam menunaikan ibadah haji memiliki berbagai macam motivasi dalam berhaji. Sepertinya predikat haji mabrur tidak menjadi perhatian mereka sebab status sosial jauh lebih penting dalam proses bermasyarakat Syariati (2009). Haji seperti itu dianggap sebagai drama kolosal yang sering dipertontonkan oleh umat manusia (Syariati, 2002;2014).

Meski tidak semua orang yang berhaji berperilaku demikian, tetapi pola berhaji seperti ini tampaknya telah menjadi selera umum di dalam masyarakat Bugis. Walaupun ada beberapa kelompok masyarakat melihat gejala ini secara kritis, tetapi mereka tidak memiliki kuasa untuk menentang praktek haji seperti ini. $\mathrm{Hal}$ ini barangkali karena fenomena tersebut di bungkus dengan kemasan ibadah atau agama, sehingga ia menjadi masalah yang seolah-olah tidak bisa dianalisis dan orang menjadi riskan mengkritiknya.

Jika segala sesuatu diukur hanya bersifat bendawi, berkarakter biologis, perangkat keras, dan perangkat lunak maka kondisi demikian melahirkan pandangan materialis bahwa ukuran kenikmatan dan keberhasilan hidup di dunia adalah ketersediaan kebutuhan benda materi. Tak pelak lagi, ketika kesenangan kehidupan dunia merajai hati seseorang, maka kedudukan dan peranan Allah kian mengecil dan bahkan hilang sama sekali dari hati manusia. Ketika itu, titik Tuhan seseorang semakin tertutupi kabut materi bendawi (Sensa \& Artyasa, 2004 Kehidupan manusia terasa sangat nyaman dan indah dalam sinergi kebutuhan jasmani dan rohani meskipun dalam kemasan simbolis ritual ibadah haji ditetapkan oleh-Nya sebagai media pembentukan karakter. Tegasnya, ritual ibadah haji adalah simbol-simbol ritual-sakral yang nilai hakikatnya harus ditangkap oleh pelakunya.

Corak yang melekat pada simbol-simbol haji yang ditujukan kepada pelakunya menunjukkan berbagai interpretasi makna dari simbol-simbol haji yang melekat pada masyarakat Bugis di Kecamatan Soppeng Riaja Kabupaten Barru. Sebagai seorang muslim bahwa ibadah haji memang pada dasarnya adalah penyempurna dari rukun Islam yang lainnya dan juga kewajiban yang harus ditunaikan seorang hamba kepada Allah SWT. Kecintaan dan penghargaan masyarakat Bugis Barru terhadap haji itu tidak dapat dipungkiri.

Selama pengamatan awal, beberapa indikasi fenomena yang muncul sebagai berikut: (1) Salah satu indikasi kecintaan dan penghargaan masyarakat Bugis terhadap haji adalah daftar tunggu calon jamaah haji di Kabupaten Barru 
sudah mencapai 35 Tahun lamanya sebagaimana yang dungkapkan oleh informan dalam penelitian ini yaitu H.S Pide sebagai pengurus Travel Haji untuk kawasan daerah Barru. Hal ini bisa dijadikan sebagai tolak ukur kecintaan mereka terhadap haji. (2) Orang yang sudah melaksanakan ibadah haji, mereka secara otomatis mendapatkan gelar haji dan dilekatkan di depan namanya; (3) Dalam kegiatan sosial keagamaan, misalnya acara pernikahan, aqiqah dan lain sebagainya, maka orang yang sudah berhaji mendapatkan posisi yang istimewa dibandingkan dengan orang yang belum berhaji di tengah masyarakat, sehingga orang yang berhaji pun biasanya memberikan tanda serta mengidentifikasi dirinya sebagai orang yang sudah berhaji sebagai cara mereka dalam mengalihkan perhatian ke masyarakat umum demi mendapatkan pengakuan.

Tujuan penelitian ini adalah untuk mengungkapkan makna simbolik haji dalam perspektif masyarakat Bugis Barru. Manfaat penelitian adalah diharapkan menjadi rujukan masyarakat di Kecamatan Soppeng Riaja Kanbupaten Barru dalam mengembangkan serta memajukan nilai-nilai agama, kebudayaan, dan tradisi-tradisi masyarakat Bugis di Kecamatan Soppeng Riaja Kabupaten Barru. Terutama mengenai penggunaan simbol-simbol haji yang dapat menghasilkan nilai manfaat terhadap masyarakat, bangsa dan negara terkhusus kepada masyarakat Soppeng Riaja Kabupaten Barru.

\section{Metode Penelitian}

Jenis penelitian ini adalah kualitatif yang bertujuan untuk memberikan gambaran secara tepat sifat-sifat suatu individu, keadaan, kelompok tertentu atau untuk menentukan frekuensi serta penyebaran suatu gejala berkaitan dengan gejala yang satu dengan gejala yang lain dalam masyarakat (Moleong, 2006). Dalam membangun penelitian ini, peneliti menggunakan jenis penelitian kualitatif dengan menggunakan pendekatan fenomenologi berbasis teori interaksionisme simbolik dengan mengacu pada Blumer (1969). Dalam hal ini penulis perlu memberikan penjelasan tentang istilah tersebut dengan melalui pendapat ahli sosiologi. Mayer dan Greenwood (1983) menyatakan bahwa "penelitian deskriptif kualitatif adalah penelitian mengacu pada identifikasi sifat-sifat yang membedakan atau karakteristik sekelompok manusia, benda, atau peristiwa".

Pendekatan fenomenologis digunakan untuk melihat persoalan-persoalan yang terjadi berdasarkan gejala-gejala. Kemudian gejala tersebut diinterpretasikan dalam bentuk uraian-uraian, pengertian-pengertian dan makna-makna dalam sebuah peristiwa. Yaitu pendekatan yang menggunakan perbandingan sebagai sarana interpretasi yang utama untuk memahami arti dari ekspresi-ekspresi keagamaan (Kahmad, 2006). Moleong (2006) menyatakan bahwafenomenologi memiliki dua pengertian sebagai berikut: (1) pengalaman subjektif manusia atas gambaran-gambaran pengalaman atau peristiwa yang terjadi; (2) Studi tentang kesadaran dari perspektif pokok dari seseorang".

Lokasi penelitian yaitu di Kecamatan Soppeng Riaja Kabupaten Barru. Penelitian ini dilakukan berdasarkan studi kasus terhadap beberapa orang yang berstatus haji di Kecamatan Soppeng Riaja Kabupaten Barru dan dilakukan studi kasus terhadap beberapa orang yang berstatus haji dengan maksud untuk mengungkapkan makna yang tersembunyi dalam simbol-simbol haji masyarakat Bugis di Kecamatan Soppeng Riaja Kabupaten Barru serta mengungkapkan 
makna dari perilaku masyarakat haji Bugis Kecamatan Soppeng Riaja Kabupaten Barru. Informan penelitian ini adalah sebagai berikut.

Tabel 1. Informan Penelitian

\begin{tabular}{clcc}
\hline No. & Nama (Inisial) & Umur & Pekerjaan \\
\hline 1 & A.G.H M. F W & 79 & Tokoh Agama \\
\hline 2 & H.M.M Arif & 52 & PNS \\
\hline & & & \\
\hline 3 & H.S Pide & 50 & Pengurus travel Haji \\
\hline & & & \\
\hline 4 & B. Hude & 56 & KASI PHU Kemenag
\end{tabular}

Teknik analisis data yang digunakan dalam penelitian ini adalah analisis data kualitatif. Adapun teknik analisis data yang digunakan, mengacu pada teknik analisis data yang digunakan oleh Miles dan Huberman (Sugiyono, 2008). Adapun model interaktif dalam analisis data oleh Miles dan Huberman disajikan pada gambar sebagai berikut:

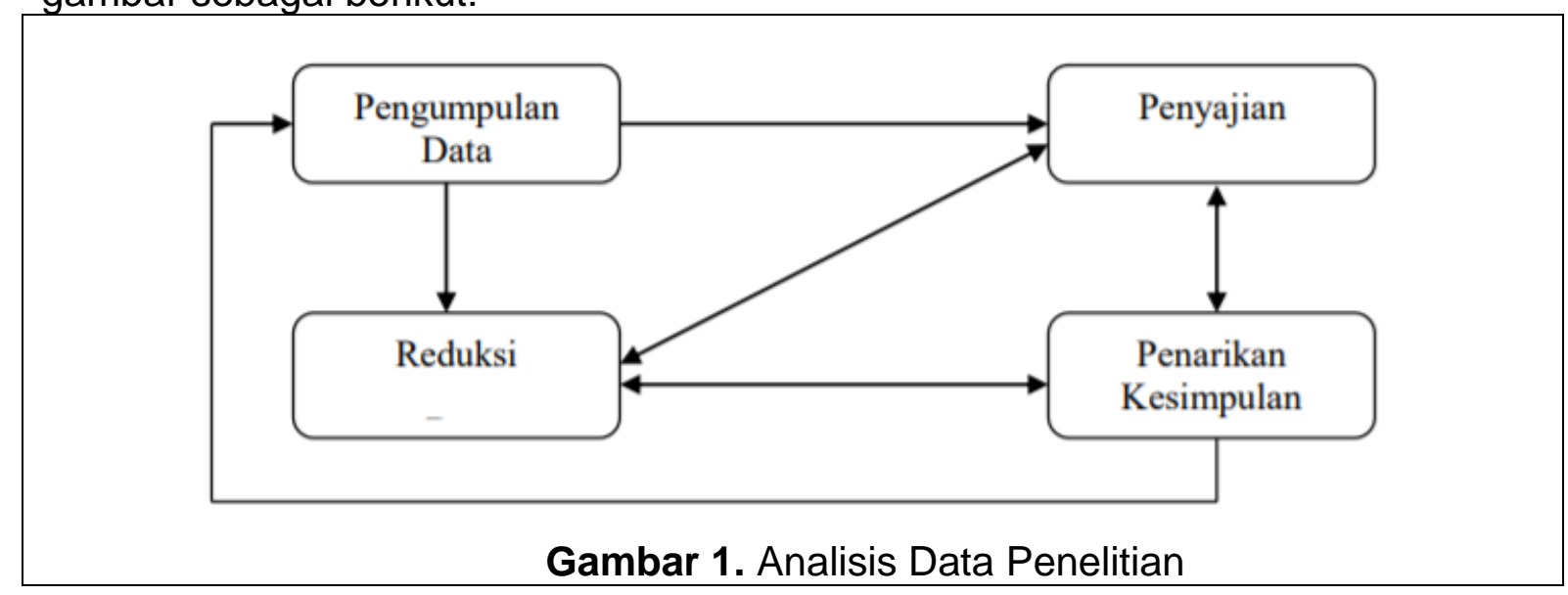

\section{Hasil dan Pembahasan}

Makna simbolik haji dalam perspektif masyarakat Bugis yang ada di Barru Kecamatan Soppeng Riaja diungkapkan ke dalam empat konsep yaitu konsep takdir, konsep kesuksesan hidup, konsep dari istita'ah, dan makna ritual mappatoppo.

\subsection{Konsep Takdir}

Masyarakat Bugis di Kecamatan Soppeng Riaja mengenal dan percaya tentang konsep takdir bila dikaitkan dengan ibadah haji, mereka menganggap bahwa melaksanakan ibadah haji bukan semata-mata karena faktor finansial atau (banyaknya uang yang dimiliki oleh seseorang) dan juga bukan karena kemampuan secara fisik, tetapi persoalan takdir. Sehingga menurut informan penelitian, H.M.M Arif, bahwa ada ungkapan dari masyarakat Bugis mengatakan; "Werepa penre'ki ri tana Mekkah" (takdir yangmenjadi penentu dalam melaksanakan ibadah haji ke tanah suci".

Salah satu alasan mereka yang bisa dijadikan sebagai tolak ukur dalam memahami takdir yang mereka maksud yakni, "ada di antara orang-orang pada masyarakat Bugis Barru di Kecamatan Soppeng Riaja, jika dilihat dari kemampuan 
secara finansial mereka sudah mapan (sudah memenuhi syarat untuk berhaji) serta sehat secara jasmani, tetapi mereka belum berhaji. Mereka hanya menggunakan uang dan kesehatan fisiknya untuk keperluan yang lain dengan alasan "De'pi gaga pangngolli'na puangnge" (belum ada panggilan dari Allah) padahal sejak dulu sudah ada panggilan dari Allah melalui Nabi Ibrahim as. (lihat Surah al-Hajj ayat 27). Sebenarnya, bagi orang yang sudah mampu secara fisik dan finansial wajib hukumnya berhaji tanpa alasan apapun. Jika keadaan sudah memungkinkan dan belum juga melaksanakannya, berarti niat orang tersebut belum ada, maka muncul ungkapan mengatakan "De'pigaga werena menre' ritana mekkah" (takdir belum berpihak kepadanya). (Hasil Observasi dan Wawancara dengan H. M.M Arif, 20 September 2021).

Ada kasus yang pernah terjadi di Kecamatan Soppeng Riaja, salah seorang imam masjid jika dilihat dari sisi finansialnya, ia sama sekali tidak memiliki modal dalam berhaji bahkan tidak mampu menabung untuk keperluan hajinya, etapi karena kehendak Allah (takdir berpihak kepadanya) maka Allah menggerakkan hati salah seorang hartawan membantu imam masjid tersebut dengan memberikan ongkos dalam melaksanakan ibadah haji. Di sisi lain, ada juga di antara orang jika dilihat dari persiapan berhajinya sudah mantap, berkas dan setorannya sudah cukup, tiba-tiba jatuh sakit maka ia tidak jadi berangkat berhaji dan digantikan oleh orang lain. (wawancara dengan H. S Pide, 20 September 2021). Begitu pula kasus yang terjadi pada tahun 2020, pemerintah sudah menetapkan nama-nama yang berangkat berhaji. Diluar dugaan, tiba-tiba datang pandemi maka semua orangorang yang sudah ditetapkan berhaji dibatalkan atau diundur keberangkatannya. Maka seperti itu yang disebut dengan takdir sebagaimana yang diyakini oleh orang Bugis.

Berkaitan dengan takdir, Menurut B. Hude. bahwa takdir itu pada dasarnya dibagi menjadi dua yaitu takdir tidak bisa dirubah oleh manusia, misalnya berkaitan dengan penciptaan alam dan manusia itu sendiri. Kedua, takdir yang diberikan kepada manusia untuk merubahnya yaitu sesuatu berkaitan dengan nasib yang disertakan dengan doa dan usaha seperti doa dan usaha keras untuk melaksanakan haji. (wawancara, 12 Oktober, 2021).

Takdir dalam gambaran secara umum adalah segala sesuatu yang terjadi setelah melalui proses, baik yang terjadi pada diri manusia maupun di luar diri manusia. Misalnya ungkapan mengatakan "Sudahlah, perkara itu sudah menjadi takdir Tuhan, tidak perlu dibicarakan lagi”. Oleh karena itu, esensi daripada takdir itu adalah kaitannya dengan suatu ketentuan ilahi yang tidak dapat kita lawan. Kita semua dikuasai oleh takdir tanpa mampu mengubahnya dan tanpa ada pilihan lain, karena takdir itu merupakan ketentuan dari Allah SWT. Maka kita hanya bisa menerimanya baik atau buruk keadaan tersebut (terkait dengan paham ahlu sunnah wal-jamaah). (Madjid, 2005).

Masyarakat Bugis di Kecamatan Soppeng Riaja memperkenalkan dua istilah takdir yakni: pertama, ada yang disebut were. Kedua, ada yang diistilahkan dengan toto'. Were dan toto' memiliki makna yang berbeda walaupun keduanya masuk dalam konsep takdir. Were biasanya dinisbahkan kepada hal-hal yang bersifat baik (positif), misalnya; "werena si A mancaji tau sugi" (takdirnya si A menjadi orang kaya). Sedangkan toto' biasanya dikaitkan dengan hal-hal yang bersifat buruk (negatif) misalnya; "toto'na Si B mancaji tau kasiasi” (takdirnya si B menjadi orang miskin). Oleh karena itu, bagi orang Bugis, dalam konsep takdir 
seseorang akan mendapatkan posisi were dalam kaitannya dengan haji, jika seseorang mempunyai niat yang kuat dan usaha yang keras untuk melaksanakan ibadah haji, maka hal tersebut akan tercapai. Sebaliknya, walaupun seseorang memiliki banyak harta dan kondisi yang prima, jika tidak dibarengi dengan ekstra niat dan usaha yang keras, maka mereka hanya mendapatkan posisi toto' (tidak melaksanakan kewajiban berhaji).

Dari uraian di atas, maka dapat disimpulkan bahwa sebenarnya takdir dalam pengertian populer itu, dapatlah juga kita benarkan sebagaimana dipahami oleh orang Bugis yang berkaitan dengan ibadah haji. Jika ditelusuri kehidupan kita, memang ada hal-hal yang sama sekali berada di luar jangkauan nalar kita untuk menolak dan melawannya. Hanya saja, jika sikap percaya kepada takdir itu diterapkan pada cara yang tidak tepat atau tidak pada tempatnya, maka akan melahirkan sikap mental yang sangat negatif dan melahirkan cara pandang fatalisme, karena sikap tersebut mengandung semangat menyerah dan kalah terhadap nasib tanpa usaha secara sungguh-sungguh, padahal Islam adalah agama yang mengajarkan pentingnya amal perbuatan.

\subsection{Konsep Kesuksesan Hidup}

Ada pemahaman dari masyarakat Bugis di Kecamatan Soppeng Riaja bahwa puncak dari kesuksesan hidup seseorang adalah setelah melaksanakan ibadah haji, tentu hal ini menjadi salah satu motivasi serta tolak ukur sehingga mereka berlomba-lomba mendaftarkan diri untuk melaksanakan ibadah haji. Memang pada dasarnya setiap manusia jika ditanya, apakah anda ingin sukses dalam hidup anda? Maka mereka menjawab iya. Karena berharganya sebuah kehidupan ada di tingkat kesuksesan. Ibadah haji hadir di tengah masyarakat Bugis di Kecamatan Soppeng Riaja menjawab semua itu dan memiliki magnet tersendiri yang dijadikan sebagai alat motivasi untuk mencapai kesuksesan, baik dalam level kehidupan dunia maupun kehidupan akhirat sebagaimana keyakinan masyarakat muslim pada umumnya.

Bagi orang Bugis, bahwasanya ibadah haji dapat melahirkan berbagai macam kesuksesan setelah melaksanakannya. Dogma ini datang dari orang tua dan secara turun temurun diwariskan kepada anak cucunya. Dalam suatu wawancara yang dilakukan oleh penulis, salah satu informan mengatakan: "Orang tua kita memberikan pesan, jika kita diperhadapkan dengan tiga pilihan untuk memilih salah satunya; membangun rumah, melanjutkan pendidikan dan berhaji. maka orang tua kita memberikan pesan, dahulukanlah hajimu karena yang lainnya akan ikut". Bagi mereka, berhaji adalah pilihan yang paling tepat untuk mendapatkan keberhasilan yang lain. (Hasil wawancara dengan H. M. M. Arif. 13 September 2021).

Sebagai penutup dari rukun Islam, ibadah haji memang memiliki peran besar menjadikan pelakunya untuk mendapatkan peluang-peluang yang berkaitan dengan kebutuhan-kebutuhannya diantaranya adalah pemahaman agama, pendidikan, hubungan sosial dan hal-hal yang berkaitan dengan ekonomi. Inti dari pesan tersebut adalah "masempo dalle' tauwwe rekko pole mekkah" (rezeki seseorang dimudahkan jika ia sudah berhaji). Islam menjamin seseorang mendapatkan dua sisi kebahagiaan, kebahagiaan dunia dan juga kebahagiaan akhirat bagi orang yang menyandang status haji 
mabrur. Kebahagiaan pada dasarnya menjadi penentu dalam kehidupan manusia karena kebahagiaan menjadi kunci untuk mendapatkan rasa aman, nyaman serta nilai keberkahan dalam melakukan aktivitas sehari-hari. Dengan demikian, ibadah haji yang mereka lakukan benar-benar telah meninggalkan sebuah pengalaman keagamaan yang luar biasa dan terkadang sulit untuk dijelaskan. Lebih daripada itu, gelar haji yang disandangnya memberikan sebuah makna hidup yang sesungguhnya karena merasa kurang sempurna keislamannya ketika belum melaksanakan ibadah haji.

\subsection{Konsep Kesuksesan Hidup}

Haji adalah ibadah yang unik, karena disatu sisi secara syariat wajib hukumnya untuk dilaksanakan bagi setiap muslim yang baligh dan berakal sehat, tetapi di sisi lain tetap mengajukan persyaratan yaitu istita'ah (mampu). Sehingga kemampuan disini diinterpretasikan secara luas oleh kalangan ulama, cendikiawan serta masyarakat.

Untuk mendapatkan istita'ah yang mengandung kesucian dan keberkahan dari hajinya maka ada beberapa hal yang harus dilalui oleh para calon haji agar tujuan dan cita-cita hajinya tercapai sesuai dengan peruntukannya. Menurut A.G. H. M. F W, jika calon haji ingin melaksanakan ibadah haji maka mereka harus membekali diri dengan lima kesucian yaitu: pertama, suci niat yaitu salah satu yang menjadi penentu keberhasilan seseorang dalam berhaji maka ia harus meluruskan niatnya terlebih dahulu sebelum berangkat ke tanah suci, dan apabila seseorang melaksanakan haji kemudian tidak dibekali dengan niat yang benar, maka boleh jadi berhajinya bukan karena Allah tapi faktor lain. Sedangkan menurut Ali Syariati bahwa "jika seseorang ingin berhaji maka ia harus mempertegas niatnya, kuatkan diri serta terangi hatimu dengan api cinta semata-mata karena Allah. Jika seseorang dulunya hanya hidup dalam kelalaian dan kebodohan, serta tidak berdaya dalam segala aspek kehidupan, seperti memperbudak diri dalam dunia kerja". Lanjutnya, tanggalkan pola hidup seperti itu, jadilah manusia yang benar-benar sadar tentang kemahakuasaan Allah (Syariati, 2010: 37).

Kedua, suci hati yaitu bersih dari penyakit-penyakit hati, baik dari segi akidah maupun dari sisi sosial. Dari segi akidah seperti tidak mempersekutukan Allah, sedangkan dari sisi sosial seperti suci dari sifat kikir, sombong, tidak suka berbantah-bantahan, tidak mencelah dan mengucilkan orang lain, jauh dari prasangka buruk dan lain sebagainya. Ketiga, suci tubuh yaitu terkait dengan dosa-dosa yang pernah dilakukan seseorang baik dosa kepada Allah maupun dosa kepada sesama manusia. Terkait dosa kepada Allah, maka seseorang harus memohon ampun kepada Allah atas dosa-dosa yang pernah dilakukan dengan memperbanyak istighfar. Sedangkan dosa kepada sesama manusia, maka seseorang harus meminta maaf kepada orang yang pernah ia sakiti serta memperbanyak silahturahmi. Keempat, suci bekal yaitu seorang calon haji hendaknya memakai uang dalam berhaji bukan dari hasil yang haram seperti uang yang dihasilkan dari judi, hasil dari menipu, hasil dari korupsi dan lain sebagainya. Begitupun juga mensucikan harta dari zakat, jika harta yang dipakai berhaji sudah sampai nisabnya. Kelima, Suci keberangkatan yaitu suci keberangkatan yang dimaksud di sini adalah seorang calon haji, jika mencari pembimbing haji hendaknya mencari 
pembimbing betul-betul ahli dalam bidang perhajian. (Wawancara, 15 September 2021).

Terkait dengan penjelasan di atas, maka pemahaman keagamaan menjadi kunci dari perjalanan kesucian seseorang dalam berhaji. Perjalanan haji memang selalu menarik perhatian masyarakat, di satu sisi haji sering menampakkan dirinya yang ideal, sesuai dengan proporsinya. Di sisi lain, kemampuan masyarakat dalam memahami haji seringkali mendapatkan banyak tantangan, kemampuan berhaji terkadang hanya dipahami dari sisi luarnya, sehingga motivasi melaksanakan haji pun bervariasi. Kemampuan berhaji dikenal oleh masyarakat pada umumnya hanya berada pada tataran kemampuan materi dan fisik, tetapi tidak dilihat dari sisi lainnya. Padahal kemampuan berhaji terbuka lebar untuk didalami serta dikembangkan pengertiannya dari berbagai situasi dan kondisi.

Jika dipetakan, ada orang mampu berhaji jika dilihat dari fisiknya, tetapi mereka tidak memiliki ongkos berhaji, maka tidak bisa masuk kategori mampu. Sebaliknya ada orang mampu secara finansial, tetapi kemampuan fisiknya tidak ada, maka mereka pun tidak masuk kategori mampu. Jika dikembangkan maknanya, ada orang mampu secara fisik dan harta, tetapi mereka tidak memiliki kemampuan psikis yaitu mampu secara intelektual dan spiritual, maka hajinya tetap dianggap sah. Menurut A.G. H. M. F W, haji seperti ini sah dimata masyarakat, tetapi dimata Allah tidak sah, karena hajinya tidak mengandung nilai-nilai intelektual dan spiritual (hajinya tidak berbekas), sehingga muncul istilah di masyarakat haji bawammi (gelarnya hanya haji), tetapi perubahan dari perilakunya ke arah yang lebih baik tidak ada.

Dalam suatu wawancara penulis dengan bapak H. M. S. Pide beliau mengatakan bahwa makna istitaah dalam berhaji mengandung tiga syarat pokok yang harus dipenuhi oleh para calon haji. Pertama adalah kemampuan fisik, artinya orang yang ingin melaksanakan ibadah haji maka harus memenuhi standar kesehatan fisik, dalam bahasa medisnya itu adalah kesehatan prima. Dalam aturan perundang-undangan tentang perhajian dikatakan, bahwa seseorang yang menjadi calon haji harus mempersiapkan kemampuan fisiknya. Oleh Karena itu, kesehatan itu menjadi hal yang sangat penting, bahkan di dalam bahasa dinas kesehatan juga terdapat istilah yang disebut istita'ah dalam perspektif dinas kesehatan berarti sehat secara jasmani.Kedua, kemampuan syar'i yaitu kemampuan dalam memahami haji ditinjau dari sudut pandang fiqhi, nilai-nilai ajaran fiqhi yang dimaksud di sini adalah hendaknya bagi calon haji harus memulai dari pemahaman dua kalimat syahadat, shalat, puasa, dan zakat baru melaksanakan ibadah haji. Bukan sebaliknya, berhaji dulu baru berusaha memahami rukun Islam yang lainnya, padahal idealnya memahami rukun Islam yang lain baru ditutup dengan ibadah haji. Oleh sebab itu, Rasulullah memberikan pesan "al-hajj qabla an-tahajjah" (berhajilah sebelum melaksanakan ibadah haji). Ketiga, kemampuan materi, secara administrasi pengelolaan keuangan haji dikelola oleh pihak pemerintah sebagai tanggung jawab terhadap masyarakatnya. Jika seseorang ingin melaksanakan ibadah haji, maka harus memenuhi kemampuan secara materi, karena melaksanakan ibadah haji membutuhkan biaya yang tidak sedikit, mulai dari persiapan pemberangkatan, proses 
pemberangkatan sampai kembali ke kampung halaman, semuanya membutuhkan biaya. Jadi, seseorang tidak boleh berhaji tanpa memenuhi kemampuan materi.

\subsection{Makna Ritual Mappatoppo}

H.M.M. Arif sebagai informan dalam penelitian ini menjelaskan bahwa setelah melontar jumrah, ritual mappatoppo dilakukan oleh jamaah haji bugis. Ritual ini berupa kegiatan menyematkan lipatan taliling atau talulu (kerudung panjang yang digulung dan dililitkan di kepala haji perempuan) serta pemakaian surban dan songkok haji bagi laki-laki sebagai bentuk peresmian penyempurnaan rukun Islam dan sebagai salah satu penguat bagi jamaah Bugis dalam melengkapi dirinya setelah berhaji di mana siap untuk melaksanakan perintah Allah SWT yang tertuang dalam rukun Islam dan siap mengimplementasikannya dalam kehidupan masyarakat . Ritual mappatoppo merupakan tradisi dari kebudayaan masyarakat Bugis yang secara turun-temurun dilakukan jamaah haji sebagai rangkaian peresmian dan tanda syukur kepada Allah SWT, atas keberhasilannya dalam melaksanakan ibadah haji setelah bertahun-tahun lamanya menunggu antrian haji.

Masyarakat Bugis membawa nilai spiritual dengan menghubungkan antara haji dengan budaya. Salah satunya dengan melakukan ritual mappatoppo untuk melengkapi dirinya dalam melakukan suatu proses yang disebut dengan haji Maqbul (haji yang dikabulkan), dengan tujuan untuk mendapatkan haji mabrur (haji melakukan kebaikan dan ketaatan). Ritual mappatoppo dianalogikan seperti sarjana yang sedang menyelesaikan kuliahnya atau sedang di wisuda dengan mengundang orang tua, sanak saudara, handai taulan dan kerabat-kerabat yang lainnya dengan maksud untuk memberikan persaksian secara akademik kepada seseorang bahwa dia sudah resmi menjadi seorang sarjana. Ritual mappatoppo merupakan rangkaian peresmian seseorang dengan mendapatkan gelar haji dan juga ungkapan kesyukuran bahwa ia sudah memulai hidup baru setelah mendapatkan gelar haji. (Wawancara dengan H. M. M. Arif, 13 September 2021).

Dalam ritual mappatoppo, sebenarnya memberikan pesan kepada masyarakat yang berhaji bahwa "anda sudah resmi menyandang gelar haji berarti jangan lagi memiliki sifat-sifat atau perilaku yang bertentangan dengan haji". Ritual mappatoppo pada dasarnya mengandung makna yang cukup mendalam seperti doa yang dipanjatkan para haji pada saat melakukan ritual mappatoppo. "Allahumma hajjan mabruran wasa'yan masykura" "Ya Allah, jadikanlah hajiku sebagai haji mabrur dan masukkan aku dalam golongan orang-orang yang bersyukur".

Kebaikan yang dimaksud dalam doa mappatoppo mencakup dari semua kebaikan dari berbagai macam kebaikan yang diperintahkan Allah kepada para haji seperti berbuat baik kepada Allah melalui shalat, berbuat baik kepada sesama manusia dengan melalui sedekah atau tidak memandang rendah orang lain, berbuat baik kepada diri sendiri dengan membiasakan berpuasa, berbuat baik kepada alam dan sebagainya.

A.G.H M. F W sebagai informan dalam penelitian mengungkapkan bahwa "makna dalam upacara mappatoppo sebenarnya dapat kita ketahui pada saat Rasulullah menyampaikan ceramahnya di Padang Arafah dengan mengatakan alhajju arafah artinya orang itu harus berkumpul di Padang Arafah dan meresapi 
nilai-nilai kemanusiaan universal". Lebih lanjut, di Arafah juga di demonstrasikan berkumpulnya segala macam bangsa, dari warna kulitnya putih, kuning sawo matang, sampai yang berkulit hitam. Menurut al-Qur'an memang manusia semuanya sama. Barang siapa memandang orang lain lebih rendah dari dirinya hanya karena warna kulitnya, tempat kelahirannya, bentuk tubuhnya dan sejenisnya maka itu diistilahkan rasisme. Dan rasisme itu dosa pertama yang dilakukan makhluk. Yaitu ketika Iblis menolak sujud kepada Adam hanya karena Iblis diciptakan dari api, dan Adam diciptakan dari tanah. Kemudian Iblis itu merasa lebih unggul daripada Adam.

Dari uraian di atas menjelaskan bahwa ibadah haji mengajarkan kepada pelakunya agar tidak menjadi angkuh, sombong dan senantiasa memahami dan mengaplikasikan bahwa pada dasarnya manusia itu sama. Haji merupakan aspek formal puncak kesempurnaan Islam seseorang maka konsekuensi sosialnya adalah seorang haji dipandang telah mencapai derajat Islam yang sempurna, meskipun pada tataran perilaku beragama tidak selamanya demikian. Artinya tidak ada kohesi antara nilai haji sebagai aspek perilaku.

Oleh karena itu, melaksanakan ibadah haji menurut ajaran Islam yang tertuang dalam upacara mappatoppo mengandung arti bahwa predikat sebagai haji mabrur tidak sekedar sebagai hadiah ketika melaksanakan ibadah haji, melainkan merupakan suatu nilai yang menuntut adanya sikap dan perbuatan yang mendukung. Setelah menyandang gelar haji maka seseorang harus berupaya memelihara sikap dan tindakan yang kurang baik yang biasa mereka lakukan sebelum naik haji, karena menurut keyakinan sebagian orang bahwa semua perbuatan dosa yang pernah dilakukan seseorang sebelum berhaji akan diperlihatkan pada saat berada di Mekah, jadi setelah melakukan upacara mappatoppo para haji dianjurkan menjaga gelar haji yang disandangnya.

\section{Kesimpulan}

Berdasarkan hasil penelitian yang telah dilakukan mengenai makna simbolik haji dalam perspektif masyarakat Bugis-Barru di Kecamatan Soppeng Riaja Kabupaten Barru, maka dapat disimpulkan bahwa makna simbolik haji dalam pandangan masyarakat Bugis-Barru dapat dilihat dari beberapa perspektif. Pertama; konsep takdir, mereka menganggap bahwa melaksanakan ibadah haji bukan semata-mata karena faktor finansial atau (banyaknya uang yang dimiliki oleh seseorang) dan juga bukan karena kemampuan secara fisik, tetapi persoalan takdir. Kedua; konsep kesuksesan hidup, mereka mempersepsikan bahwa puncak dari kesuksesan hidup seseorang adalah setelah melaksanakan ibadah haji. Ketiga; Istita'ah, pada umumnya masyarakat Bugis Barru melihat istita'ah dalam berhaji hanya dari dua sudut pandang yaitu mampu secara fisik dan finansial. Keempat; Ritual mappatoppo, merupakan rangkaian tradisi dari kebudayaan masyarakat Bugis sebagai peresmian dan tanda syukur kepada Allah SWT atas keberhasilannya dalam melaksanakan ibadah haji setelah bertahun-tahun lamanya menunggu antrian haji.

\section{Daftar Pustaka}

Blumer, Herbert. (1969). Symbolic Interactionism: Perspective and Method. New Jersey: Prentice Hall 
Kahmad, Dadang. (2006). Pendekatan Sosiologis dalam Studi Agama. Bandung: Remaja Rosdakarya.

Moleong, Lexy J. (2006). Metode Penelitian Kualitatif. Bandung: Remaja Rosdakarya.

Mayttulada. (1980). Manusia dan Kebudayaan Bugis Makassar. Jakarta Timur: Rawamangun

Mattulada. (1985). LATOA: Suatu Lukisa Analitis terhadap Antropologi Politik Orang Bugis. Yogyakarta: Gadjah Mada University Press.

Mayer \& Greenwood. (1983). Rancangan Penelitian Kebijakan Sosial. Jakarta: Rajawali.

Rustan, Ahmad Sultra. (2018). Pola Komunikasi Orang Bugis: Kompromi antara Islam \& Budaya. Jakarta: Pustaka Pelajar.

Sensa, Muhammad Djarot \& Artyasa, Usin S. (2004). Haji Spiritual:Makna Filosofis-Esoteris dalam Pendakian Ruhani. Bandung: Tafakur (Kelompok Humaniora)-Anggota IKAPI.

Sugiyono. (2008). Memahami Penelitian Kualitati. Bandung: Alfabeta.

Syari'ati, Ali. (2002). Haji. Penerjemah: Anas Mahyudin. Bandung: Penerbit Pustaka.

Syariati, Ali. (2009). Rahasia Haji (Berjumpa Allah di Ka'bah Hatı). Terjemahan oleh Yuliani Liputo. Bandung: Mizan.

Syariati, Ali. (2014). Makna Haji: Berhaji adalah Perjalanan menuju Serambi Surga, Siapa yang Memaknai Hajinya dengan Benar, maka Surga adalah Ganjarannya. Yogyakarta: Zahra. 